\title{
Cтатьи
}

\section{КРИТИКА ПСИХОЛОГИИ ВО ФРАНЦУЗСКОЙ ФИЛОСОФИИ СЕРЕДИНЫ ХХ В. В СВЕТЕ «СПОРА О ПСИХОЛОГИЗМЕ»}

\author{
О.А. ВЛАСОВА \\ ${ }^{a}$ Санкт-Петербургский государственный университет, 199034, Россия, Санкт-Петербург, \\ Университетская наб., д. 7/9
}

\section{Резюме}

В статье анализируется философская критика психологии во Франции 1940-1950-х гг. в свете спора о психологизме и на материале идей Ж. Политцера, Ж.-П. Сартра, Д. Лагаша, Ж. Кангилема, М. Фуко. Показана продуктивность применения терминологии «спора о психологизме» по отношению к французской ситуации, характеризуется национальная специфика критики. Философская критика психологии развивается во Франции гораздо позже, чем в Германии, что связано с более длительным процессом обособления психологии от философии. Статья выстраивает хронологию развития психологии как двухэтапный процесс ее институционализации как науки (1870-1940-е гг.) и специальности (1940-2000-е гг.). Всплеск философской критики приходится на 1940-1950-е гг. - десятилетие, когда психология получает право на лиценциат. Автор доказывает, что психологи и философы сталкиваются не непосредственно друг с другом, а в поле философской антропологии, и психология здесь претендует занять место не философии, а основной гуманитарной науки. Психологизм во Франции 1940-1950-х гг. связан с претензиями психологии стать основанием антропологии. Антипсихологизм, развитый в рамках философской критики психологии, есть тенденция отстоять философский статус антропологии и доказать, что только при сохранении философской базы антропология может постичь человека как целостность. Философы акцентируют два проблемных момента психологии: 1) отсутствие целостности, разнонаправленность теорий и объяснительных схем, 2) донаучный или мифологический характер ее постулатов. Они расценивают философский критицизм как пропедевтику к антропологии (материалистической или экзистенциальной) и трактуют психологию как исходную точку нового кантианского проекта, а также новой философии науки (как науки о человеке). В этом движении автор выделяет вектор «Политцер Сартр - Лагаш - Кангилем - Фуко» и подробно анализирует характер критицизма каждого из мыслителей.

Ключевые слова: французская философия, психология, антропология, спор о психологизме, антипсихологизм, Ж.-П. Сартр, Ж. Политцер, Д. Лагаш, Ж. Кангилем, М. Фуко.

Работа подготовлена в рамках гранта для преподавателей магистратур Стипендиальной программы Благотворительного фонда В. Потанина, проект № ГК 170000801. 
Известно, что психология прошла сложный путь обособления от философии, и до настоящего времени память об этом процессе проступает в немецкой герменевтике и феноменологии, в англосаксонской философии сознания и французской эпистемологии. В первой половине ХХ в. философию и психологию объединяло слишком многое, и многочисленные следы «единства и борьбы» в истории этих наук неудивительны: психологи и философы работали на одних кафедрах, боролись за ставки, получали одинаковые степени, но в общем-то занимались разными вещами.

История сложных отношений психологии и философии на немецкой почве, той почве, которая, как считается, породила психологию как науку, достаточно хорошо представлена в критической литературе. Она - обязательный пункт изысканий в исследованиях развития феноменологического движения (Rath, 1994; Bernet et al., 1993; Varga, 2010; Mohanty, 1997; Hopkins, 2006; и др.), причем этот канон сохраняется и в русскоязычных публикациях (Мотрошилова, 1968, 2003; Куренной, 2002, 2010). Прояснение характера этих отношений в Америке тоже имеет достаточно долгую традицию (Kusch, 2005; Бен-Дэвид, Коллинз, 2006), которая до сих пор поддерживается актуальностью междисциплинарных исследований сознания в англосаксонском мире. Французская сцена представляет собой исключение: вплоть до последних лет тема «философия и психология» продолжала оставаться актуальной, но не составляла проблемы критических и исторических изысканий. Единичные работы малого формата, конечно же, существуют (см.: Braunstein, 2012), вышли единичные монографии (Engel, 1966), но отсутствие пристального внимания к этой теме на протяжении десятилетий по-прежнему приводит к сохранению белых пятен в истории французской философии ХХ в. Почему так произошло, в чем специфика французской ситуации в философии и психологии и что может дать ее прояснение - насущные вопросы.

\section{Французская специфика «спора о психологизме»}

Франция конца XIX - середины XX в. переживает ту ситуацию, которую по отношению к Германии принято обозначать как «спор о психологизме». Однако это не означает, что она вызывается одними и теми же детерминирующими факторами и имеет сходные аспекты. Немалые различия немецкой и французской сцен спора о психологизме как раз и приводят к тому, что классические исследовательские наработки в отношении немецкой традиции редко используются в объяснении явлений, которые связаны с развитием критики психологизма во Франции. И здесь необходимо говорить одновременно о содержательных и институциональных аспектах различий.

Французская метафизическая традиция никогда не обходила психологию стороной. Несмотря на противопоставление метафизики и философии, эмпирического и метафизического уровней, в котором французские философы шли вслед за немецкими (Carroy et al., 2006, p. 9), познание психологических феноменов было неотъемлемой задачей философского постижения мироздания. Мен де Биран уделял большое внимание исследованию внутреннего чувства и 
жизни сознания, воспринимая прояснение первоначальных фактов сознания как фундамент метафизики (см.: Кротов, 2000). Виктор Кузен расценивал психологию как основание метафизической онтологии и сделал немало в разработке метода внутреннего наблюдения (Кротов, 2003). Вполне спиритуалистской по духу в плане отношений философии и психологии как метафизической онтологии и метафизической антропологии выглядит и система А. Бергсона, испытавшего значительное влияние Мен де Бирана, преподававшего психологию и основавшего на ней часть своей теории (Блауберг, 2003).

Теоретические увлечения французских спиритуалистов нашли отражение в их практической деятельности. Когда Виктор Кузен стал работать на государственной службе, он сразу же воспользовался предоставленной возможностью «психологизации» образования: доктрина Мен де Бирана нашла отражение в государственных реформах, и в 1832 г. Кузен перестроил систему теологического образования. Если ранее она включала преподавание логики, метафизики и морали, то теперь ее блоками стали психология, логика, мораль и история (Carroy et al., p. 17-18). Таким образом, Кузен подготовил институциональную почву для появления новой науки: психология преподавалась всем студентамтеологам и философам, а преподавали ее философы. Этот шаг, разумеется, не был одобрен французскими позитивистами, и практически сразу же Конт с последователями заклеймили психологию как мифологическую, иллюзорную науку, не отвечающую критериям объективности. Эти обвинения впоследствии станут неотъемлемой частью французской философской критики.

Если психология была настолько органична французской философии, в силу каких факторов в XX в. начинает развиваться такая интенсивная критика и в чем ее специфика? Является ли эта критика критикой психологии, критикой психологизма или она имеет какую-то иную направленность?

В статье «Психологизм и его критика Эдмундом Гуссерлем» В. Куренной, ссылаясь на М. Рата, пишет о том, что «спор о психологизме в немецкой философии следует анализировать в перспективе отделения психологии от философии и превращения ее в самостоятельную научную дисциплину, то есть в контексте процесса, который завершается дисциплинарной институализацией психологии. <...> Таким образом, сам спор является оформлением дисциплинарно-институционального развода философии и психологии» (Куренной, 2010, с. 174). На немецкой почве институционализация психологии традиционно связывается с появлением кафедр психологии, спор о психологизме часто трактуется как «спор о кафедрах» и привязывается ко времени рубежа XIX-XX вв.: после Первой мировой войны его интенсивность угасает, поскольку немецкая психология превращается в прикладную науку, больше не претендуя на основополагающий статус философии (Куш, 2002). Творцом философской программы психологизма традиционно называется Ф.Э. Бенеке, а сам термин «психологизм» возводится к 1866 г., когда по отношению к ней этот термин использует И.Э. Эрдман (Kusch, 2005, p. 98-100).

Жан-Франсуа Браунштейн показывает, что во Франции термин «психологизм» начинает употребляться раньше, чем в Германии, и споры о психологизме не являются исключительно немецким явлением (Braunstein, 2012). Хотя в 
научной литературе, в частности в словарях, понятие «психологизм» появляется в начале ХХ в. (1906-1907) и связывается с немецкими спорами, французскую полемику о психологизме следует отнести скорее к 1830-1840-м гг., а первое употребление термина «психологизм» на французском языке можно обнаружить в 1828 г. Спор о психологизме зарождается в полемике философов В. Кузена, расценивающего психологию как пропедевтику к философии, и его ученика Т. Жуффруа, отстаивающего использование экспериментальных методов по отношению к внутреннему опыту, с врачом Франсуа Бруссе, всячески защищавшим медицину и физиологию от философского нашествия и жестко критиковавшим концепцию внутреннего опыта сознания. Бруссе поддерживает ярый противник психологии О. Конт, и, как показывает Браунштейн, именно Конт в 1928 г., говоря о работе Бруссе, использует термин «психологизм» для обозначения мишени его критики. К полемике присоединяются другие врачи и философы, и до конца 1930-х гг. она не стихает, а термин «психологизм» начинает использоваться для характеристики последствий обращения к внутреннему опыту сознания и разработки в его отношении метода наблюдения.

На основании штудирования полемики Браунштейн заключает, что в спор о психологизме во Франции было вовлечено слишком много представителей разных дисциплин (философии, физиологии, психологии, социологии), в нем заметно много политических и религиозных коннотаций. Сравнивая его с немецкой полемикой, он подчеркивает: «Он не был следствием конфликта дисциплин, философии и психологии, поскольку в этом действе было, по меньшей мере, трое действующих лиц. Вначале физиологи и врачи противостояли психологам: Бруссе против Жуффруа. Затем врачи выступили против философов: Бруссе против Кузена. Наконец, поспорили сами философы: вначале Конт, а затем и Леру с Кузеном. Эти академические конфликты не всегда имеют одни и те же истоки. <...> Как бы то ни было, проблема психологизма не была исключительно психологической» (Braunstein, 2012, p. 212). Этот вывод согласуется с итогами других исследований.

Как показывают Дж. Бен-Дэвид и Р. Коллинз, французская психология как предметное и ролевое поле была достаточно разношерстна. Нельзя сказать, что она развивалась полностью под влиянием немецкой традиции, в рядах французских психологов были и вполне самостоятельные теоретики. Однако говорить о школах здесь также не приходится: у великих отцов французской психологии (например, Рибо или Жане) было немного известных учеников. Все занимались разными областями, многие были выходцами из разных наук. В общем-то здесь мало кто с кем конкурировал и «гибридизация ролей» (процесс конкуренции за ставки между специалистами психологами и философами) была недостаточно выражена (Бен-Дэвид, Коллинз, 2006, с. 50).

Возможно, именно указанная ситуация стала одним из факторов очень долгой институционализации психологии во Франции ${ }^{1}$. Теоретический фундамент

\footnotetext{
${ }^{1}$ Поворотным считается 1870 г. (Carroy et al., 2006, p. 29). Хронологию институционализации психологии мы приводим на основании материалов указанной работы.
} 
этого процесса составляют работы И. Тэна и Т. Рибо, принесших идеи английского позитивизма и заложивших основы психологии как эмпирической, экспериментальной науки. Вслед за теоретическим прогрессом следует прогресс институциональный: во Франции начинают появляться журналы, общества, лаборатории. В 1876 г. Рибо основывает журнал «Revue philosophique de la France et de l'étranger», в котором на фоне традиционных философских проблем первенство берут проблемы психологические. В 1895 г. Анри Беани и Альфред Бине запускают «L’Année psychologique», первый исключительно психологический журнал во Франции. В 1885 г. учреждается Общество физиологической психологии (под председательством Шарко и вице-председательством Жане и Рибо). При содействии Поля Жане в Сорбонне открывается профиль «сравнительная и экспериментальная психология», Рибо получает кафедру экспериментальной психологии в Коллеж де Франс, и это событие становится первым институциональным прецедентом. В 1900 г. кафедра современной философии Коллеж де Франс достается Г. Тарду и становится кафедрой социологической психологии. Философы начинают уступать психологам свои посты. В рамках всемирной выставки Шарко организует два психологических конгресса. В 1889 г. Рибо вместе с Беани открывают первую психологическую лабораторию, и, начиная с этого момента, лаборатории появляются одна за другой: они не составляют конкуренции кафедрам, однако их структурирование как новых единиц университетской системы способствует институциональному внедрению психологии. В 1900 г. при иностранном финансировании открывается Институт психологических исследований, так начинается первая фаза институционализации.

При этом появление психологии как новой предметной и исследовательской области сопровождается скорее обоюдным интересом философии, психологии и медицины, чем ожесточением и полемикой. Увлечение исследованием внутренней жизни сознания, философией и психологией аффектов, исследованиями психических процессов в норме и патологии, прояснением состояний сомнамбулизма объединяет специалистов в содержательном поиске. Методологические диспуты в это время хотя и встречаются, но не определяют отношений. Имеет место своеобразная захваченность новым полем исследований, в котором пока хватает места всем.

Учитывая традицию метафизической психологии и одновременно долгую институционализацию психологии, можно говорить, что спор о психологизме имеет место во Франции в стертом виде и датируется 1920-1950-ми гг. - временем, когда в амбивалентном векторе «философия - психология» меняется распределение линий напряжения и тон начинает задавать не философия, а психология.

\section{Философский критицизм}

Философская критика психологии во Франции отталкивается от той же точки, что и в Германии: в 1920-1930-е гг. признание кризиса психологии самими психологами (Куш, 2004, с. 190) развязывает философам руки. 
Однако формирование более или менее устойчивой традиции философии переводит ее в другой по сравнению с немецким модус. Основной критической точкой становится не столько сама возможность перенесения психологических данных в философскую плоскость, сколько возможность построения на фундаменте психологии целостного знания о человеке, т.е. развитие философской антропологии. Критика идет в двух направлениях: во-первых, психологии вменяется в вину отсутствие целостности, разнонаправленность ее теорий и объяснительных схем, а, во-вторых, самым уничижительным упреком оказывается упрек в ненаучном, донаучном или мифологическом характере ее постулатов. Философский критицизм представляется при этом некоей пропедевтикой к возможной (материалистической или, напротив, экзистенциальной) антропологии, а психология - исходной точкой нового кантианского проекта, а также новой философии науки (как науки о человеке). И в этом движении заметен вектор: Политцер, Лагаш, Кангилем, Фуко.

Психологизм во Франции, стало быть, связан не с попыткой «сделать психологию основанием философии и наук» (Kusch, 2005, p. 3), а с претензиями психологии стать основанием антропологии. Антипсихологизм, развитый в рамках философской критики психологии, есть тенденция отстоять философский статус этой антропологии и доказать, что только при сохранении опоры на философию антропология может постичь человека как целостность. Психологи и философы сталкиваются не непосредственно друг с другом, а в поле философской антропологии, которая мыслится первыми как цель новой науки психологии, уровень рационального целостного осмысления человека на основании данных эмпирических исследований, а вторыми - как прикладной онтологический проект. Причем антипсихологистские настроения философов связаны, как ни парадоксально, с развитием психологистских тенденций в самой философии, поскольку возможность оценки антропологии как одного из центральных философских проектов уже предполагает «нисхождение» к психологизму.

Психология здесь претендует занять место не философии, а основной гуманитарной науки. В разношерстном и подчас не дифференцированном предметном поле французской мысли, где гуманитарные науки стремительно развиваются, где медицина, психоанализ, этнология, лингвистика, история с разных сторон познают человека, включая его в многообразные контексты, основополагающим оказывается место объединяющего их центра. Философия, утрачивающая вследствие развития позитивных наук, собственного кризиса, а также всплеска гуманитарных исследований свое фундирующее положение, атакует психологию, чье развитие и первичная институционализация в это время позволяют подозревать ее в претензиях быть основой гуманитаристики. Очень хорошо эту ситуацию описал Эллиот Соубер: «На самом деле это время эмансипации было также и временем изгнания: когда психологи уходили, философы захлопывали за ними двери» (Sober, 1978, р. 165). Здесь философы стремились определить условия, при которых пустят психологов «погостить» ради построения полноценного про- 
екта антропологии, однако никак не были готовы к тому, чтобы уступить им статус хозяев.

Теоретической почвой антипсихологистской атаки и ее пусковым моментом становится проект конкретной психологии Жоржа Политцера. В работе «Критика оснований психологии» (Politzer, 1928) молодой (и еще не примкнувший к марксистам) философ всячески ратует за развитие новой психологии, теперешняя психология, по его мысли, должна быть изжита. «В самом деле, - рассуждает он, - возможно, что реформа должна состоять в том, чтобы порвать со всей той психологией, какой она была до сих пор. Кто знает? Возможно, что “психология” - это лишь иллюзия философов, принятая всерьез физиологами, а сама идея научной психологии - выдумка двух последних поколений» (Политцер, 1980, с. 244). Стало быть, обновление психологии - не в преемственности, а в разрыве с наследием и классической традицией. Пока психология не избавилась от ошибок философской психологии, продолжением которой стала даже в своей физиологической версии (у В. Вундта), она не является научной, но может быть квалифицирована только как мифологическая.

В обосновании критического посыла Политцер категоричен: «Беда не в исследованиях, часть которых находится на правильном пути, а в теории, в которой нет почти ничего такого, что должно было быть. Следовательно, положение таково: по нашему мнению, необходима прежде всего критика...» (Там же, с. 331-332). Критика должна перейти от формы к сущности, обратиться от разбора многочисленных психологий к основам психологии как таковой, и тогда оказывается, что она не соответствует не только критериям науки в общем, но и тем принципам научности, которая сама же и постулирует. Для того чтобы стать психологией не мифологической и иллюзорной, а конкретной, Политцер предлагает ей обратиться к тем формам, которые адекватны исследуемым ею объектам, т.е. к драматической стороне человеческой жизни как «фрагменту жизни отдельного индивида». Политцер объединяет в понятии «материальная мизансцена драмы» опыт человека, условия его жизни, окружающие объекты, отношения между людьми, т.е. объективное и субъективное, физиологическое и психологическое. Так он подбирается к той целостности, которую должна исследовать научная психология, причем целостности не в абстрактном, а в конкретном содержании.

Конкретность теории - обязательное требование французской критики психологии, объединяющее представителей разных направлений. Антропологизация и конкретизация, что философы видят в прочтении Гегеля Кожевым, находит свое воплощение и в философском толковании психологии. Характеризуя поколение 1930-х гг., В. Декомб заявляет: «Восстав против университетского идеализма, оно требует того, что именует “конкретной философией”, позднее ее назовут экзистенциализмом» (Декомб, 2000, с. 21). Конкретность философия находит в психологии, и сюда корнями уходят требования пересмотра абстрактных постулатов психологии, разработки ее как конкретной «почвы» философии, требования целостности не только как целостности теории, но как целостности научного исследования. 
Восстание «против университетского идеализма» оборачивается у Политцера восстанием против университетской дисциплинарной сетки, против нарождающихся кафедр и постепенно отвоевывающей себе место психологии. Психологический критицизм марксиста Политцера будет восприниматься в этом ключе многими его известными последователями и критиками. «Все в этой работе свидетельствует о старании автора выйти из университетского дискурса, плотью от плоти которого он является. И он прекрасно чувствует, что есть лесенка, по которой из него можно выбраться» (Лакан, 2008, с. 77-78), - говорит Ж. Лакан в цикле семинаров 1969-1970 гг. «Изнанка психоанализа». Фундаментальной работой для современной культуры назовет ее Л. Альтюссер (Althusser, 1996, р. 35), прямо заявив: «Политцер - Фейербах нового времени: его “Критика оснований психологии” есть критика спекулятивной психологии от имени конкретной психологии» (цит. по: Bianco, 2015, p. 12).

Политцер - предшественник. Джузеппе Бьянко даже говорит о явном или неявном присутствии Политцера в работах большинства послевоенных философов Франции: «...Сартр, Лакан, Мерло-Понти, Рикер и Лагаш присваивают темы и философемы “Критики оснований психологии”, не признавая истинного отцовства» (Ibid.). В этот ряд можно добавить имена Кангилема и Фуко.

Всплеск критицизма по отношению к психологии наблюдается во Франции в 1940-1950-е гг., и это время связано со второй фазой институционализации психологии как науки и специальности. Уже есть лаборатории и кафедры, выходят работы, психология уже обзавелась своими звездами первой величины: Жане, Бине, Рибо, Тард. Как наука психология вполне закрепилась, теперь начинается ее развитие как специальности, которое будет не менее долгим (если датировать первую фазу 1870-1940-ми, а вторую 1940 2000 -ми гг. ${ }^{2}$ ). Благодаря декрету от 9 мая 1947 г. на филологических факультетах открывается лиценциат по психологии. Правда, вначале преподавателей хронически не хватает, получить такое образование можно только в Париже, Бордо, Страсбурге и Лионе. Психологи прекрасно осознают специфику времени: в 1947 г. Даниэль Лагаш в своей инаугурационной лекции по случаю вступления в должность заведующего кафедрой общей психологии в Сорбонне говорит о поворотных временах и о миссии современных психологов (Scudéri, 2012). Это годы ухода пионеров психологии: в 1949 г. Коллеж де Франц оставляет А. Валлон, в 1946 г. умирает Ж. Дюма, а в 1947 г. - П. Жане. Психология начинает искать новые пути. Неудивительно, что со стороны философов следует реакция: кто такие психологи и чем они занимаются, чем отличаются выпускники с новым дипломом и на что они претендуют? Эти вопросы - центральные для философской критики.

Обсуждение указанных вопросов становится немаловажным и для идентификации самой философии: критика психологии является частью критического осмысления путей философии того времени (Descombes, 1989). Блуждания вокруг проблемы субъекта, поиски новых интерпретаций в гума-

\footnotetext{
${ }^{2}$ Только в 1985 г. официально легализуется профессия психолога, психотерапевты ждут легализации своей профессиональной деятельности во Франции до 2000-х гг.
} 
нитарных науках, увлечение психоанализом и психиатрией обращают философию к методологическому уровню психологии, и здесь она во многом не может пойти дальше Политцера. Психология в то время мыслится философами как прикладная, конкретная философия. В чаяниях психологии как конкретной философии марксизм удивительно един с экзистенциальной философией, предвосхищая тот синтез экзистенциального марксизма, который станет в 1960-е гг. основанием антипсихиатрии в Великобритании и Франции.

К конкретности психологию призывает в своем экзистенциальном психоанализе Ж.-П. Сартр в работах по психологии эмоций и сознания, не просто настаивая на пересмотре классической позиции феноменологии, но, как подчеркивает Арно Томе, развивая ту же философскую перспективу критики психологии, что и Политцер. Среди общих критических точек: формирование методологического фундамента психологии по шаблону естественных наук и, как следствие, описание человеческих феноменов (имеющих смысл) как феноменов природы. Разница позиций, на его взгляд, состоит лишь в том, что в своем проекте конкретной психологии Политцер ориентируется на психоанализ, в то время как Сартр избирает феноменологию Гуссерля и Хайдеггера (Tomè, 2012, p. 230).

В основании предлагаемого Сартром метода - прояснение фундаментального выбора, который определяет комплекс черт характера, обстоятельств жизни, саму биографию человека ${ }^{3}$. Выбор как таковой выражается в каждом качестве и каждой мысли, представляя собой бытийную подоплеку индивидуально-психологического портрета личности и ее поведения. Сартр настаивает: «Выбор остается единственным и с самого начала является конкретностью; отдельные действия могут выражать или характеризовать, выделять этот выбор, но они не могут его конкретизировать более, чем он уже есть. Именно этот выбор есть не что иное, как бытие каждой человеческой реальности...» (Сартр, 2004, с. 575) Прояснение выбора и его осознание приводит человека к самому себе и одновременно к пониманию своей природы как человека, поэтому Сартр сводит в экзистенциальном психоанализе два уровня: уровень феноменологической онтологии и уровень конкретной психологии, связывая психологию с философией.

Критика философии находит отклик и в самой развивающейся психологической науке. Ее первые лица обнаруживают те же самые мишени, предлагают те же теоретические ходы и сами обогащают впоследствии философскую критику, направляя ее дальнейшее движение. Самым ярким примером подобного созвучия и влияния во Франции являются идеи Даниэля Лагаша. Этот мэтр психологии, можно даже сказать - законодатель мод в критике, продвигается по той же траектории, что и его коллеги-философы.

В работе «Единство психологии» (Lagache, 1949b), а также в статьях того времени он пытается разобраться с царящей в психологии неразберихе идей.

\footnotetext{
${ }^{3}$ О психологии Сартра как развивающемся проекте см.: Mouzet, 2015. О связи психологии и метафизики и их обоюдном влиянии в послевоенной Франции см.: Fruteau de Laclos, 2015.
} 
Ставя задачу упорядочивания, он объединяет их, исходя из полярностей теории и практики, конкретной и абстрактной психологии, исследований нормы и патологии, организма и среды, поведения и сознания, поведения и значения, психического и соматического, сознательного и бессознательного, индивида и общества, прошлого и настоящего и пр. Лагаш расценивает существующее положение дел как наследие классической психологии и описывает его следующим образом: «Современная психология... показывает примечательную тенденцию исходить не из оппозиции понятий, а из взаимосвязанных реальностей, к которым они отсылают; кроме того, таким образом преодолевается существующая “апория”, а язык становится хотя и более сложным, но в наибольшей степени адекватным положению дел. И находится все больше и больше фактов, иллюстрирующих эту тенденцию» (Lagache, 1949a, p. 2). Противоположные понятия словно конституируют самостоятельные реальности, которые и изучаются психологией, давая ей безграничный горизонт исследований. Обращение к каждой из полярностей приводит Лагаша к мысли о том, что они не отражают реальности, что необходима работа по нахождению «общей категории», промежуточного пространства, по последовательной иерархизации и синтезу. Пока же психология если и призывает, то к ограниченному частичному синтезу.

Лагаш не говорит о союзе психологии и философии и не настаивает на метафизическом синтезе. Напротив, в противопоставлении наук о природе и наук о человеке, в оппозиции экспериментальной и клинической психологии Кристоф Скудери в своем диссертационном исследовании усматривает имплицитную отсылку к оппозиции психологии и философии. Лагаш говорит о синтезе в пределах психологии, о ее собственном уровне обобщения. Однако, хотя его критический пафос возник в рамках психологии, он отсылает нас не к экзистенциально ориентированной (гуманистической) критике, а скорее к эпистемологической, неслучайно он оказывается источником философской эпистемологии психологии.

Попытка отыскать единство психологии продолжается в ранних работах Мишеля Фуко (см.: Власова, 2009, 2015). В конце 1940-х - начале 1950-х гг. он посещает лекции Лагаша. Неслучайно выделенные последним оппозиции понятий становятся одним из сюжетов статьи «Психология с 1850 по 1950 г.». Если дополнить этот сюжет Политцеровым о многообразии психологий, их количественном разрастании и экспансии исследования в психологии, то ранние историко-эпистемологические прозрения Фуко не кажутся принципиально новыми. Он продолжает традицию философской критики, только перемещает ее в другую плоскость.

Если говорить о ранних работах, то статья «Психология с 1850 по 1950 г.» в большей степени развивает посыл Лагаша. Здесь заметны характерное для «Единства психологии» противопоставление наук о природе и о человеке, а также попытка рассмотреть психологию как объективную науку в оппозициях понятий и опорных точек: элементы и ансамбли, эволюция и генезис, показатели и способности, выражение и характер, поведение и институции. Фуко, продвигаясь в игре понятийных опор, показывает, что за привычными 
теориями и концептами стоят глубинные основания, которые психология должна пересмотреть. Привлекая также концептуальные ходы «Структуры поведения» М. Мерло-Понти, он демонстрирует, как в своих мытарствах последнего столетия психология пыталась обрести понятийное успокоение и забыть о фундаментальных проблемах. И вот здесь как раз в его устах оживает посыл Политцера, которым вдохновлена статья «Научное исследование и психология».

Опорная точка Политцера и Фуко - постулирование необходимости разрыва современной психологии с психологией классической (Фуко, 2015, с. 199). «Научное исследование» и «научная психология», как демонстрируют оба критика, для современной психологии всего лишь мечта, миф, посредством которого она поддерживает преемственность со своей классической традицией и с традицией объективной науки в лице физиологии. Если Политцер показывает, что исследования психологии множатся день ото дня, не углубляясь к основаниям, то Фуко вдобавок отмечает их важную функцию верификации мифологического тела психологии: они подтверждают друг друга, создавая массив психологической теории. Если Политцер критикует донаучный или ненаучный характер классической психологии и приходит к выводу о ее мифологическом характере, то Фуко вменяет эту мифологичность самой психологии, говоря о ее детскости как неспособности обрести самосознание науки (Там же, с. 277).

Выход таков же, каким мыслит его большинство критиков, - в ориентации на конкретику, что для Фуко представляется обращением к существованию конкретного человека и одновременно к истории. «...Психология является эмпирическим анализом того модуса, которым человеческое существование раскрывается в мире», - заключает он и разъясняет, что в этой задаче она «была бы возможна лишь как анализ условий существования человека и оживление наиболее человеческого в человеке, т.е. его истории» (Там же, с. 228, 230).

Так критика психологии становится исходным моментом развития антропологического и исторического проекта. Основным при этом является вопрос о самосознании - этот вопрос ляжет в основание археологии гуманитарных наук, и археология психологии станет первой подобной попыткой. В интервью Аллену Бадью в 1965 г. Фуко говорит о том, что проблема идентификации, философская критика и вообще сложные отношения с философией проблема не исключительно психологии, с ней столкнулись все гуманитарные науки. «...Начиная с девятнадцатого века сама психология и благодаря ей гуманитарные науки в целом выстраивают очень запутанные отношения с философией» (Foucault, 2001, p. 467). Психология здесь является наиболее характерным примером, а не исключением из правила, и пример этот отражает то, что Фуко в своих более поздних работах назовет «антропологическим сном» - стремлением выстраивать науку с опорой на идею человека.

В исследованиях самосознания психологии как науки Фуко близок к своему наставнику Ж. Кангилему: свои ранние штудии патологии он развивает под влиянием «Нормального и патологического» (Canguilhem, 1966), а исследования 
психологии идут параллельно поискам учителя. В декабре 1956 г. в выступлении на конференции в Париже ${ }^{4}$ Кангилем напрямую ставит вопрос об идентификации психологии и начинает свою речь длинным и уничижительным пассажем: «Вопрос “Что такое психология?” для психолога кажется еще более затруднительным, чем вопрос “Что такое философия?” для философа. < ..> В то же время для психологии вопрос о ее сущности, или, если выразиться скромнее, о ее понятии, ставит под сомнение само существование психолога: если он бессилен дать точный ответ на вопрос, что же он есть, то затруднительно определить и то, чем он занимается. И только в эффективности его деятельности, которая, впрочем, весьма спорна, следует искать обоснование его значимости как специалиста, значимости, которая, не в обиду будет сказано, вызывала бы у философа комплекс неполноценности» (Кангилем, 2012, с. 212).

В свете провокативности этого высказывания заявление о том, что Кангилем отвадил от психологии целое поколение философов, представляется совершенно правомерным (Engel, 1966, p. 12). Элизабет Рудинеско вообще напрямую заявляет, что Кангилем, даже если и не признается в открытую, но жаждет смерти психологии, что он разрушает здание той науки, которую с 1949 г. строил его друг Д. Лагаш, что как марксист и участник Сопротивления он воспринимает психологию как «фашистскую» (Roudinesco, 1993).

Как историк науки и человек, который смотрит вглубь проблемы идентификации, Кангилем настаивает на том, что вопрос идентификации не должен приводить к утверждениям о мифологичности или иллюзорности психологии, но статус психологии и ее эффективность обосновываются самими психологами в манере, которая не всегда соответствует критериям научности. Психология вольна, насколько вольной может быть новая наука, расширяющая границы закостенелых дисциплин, и Кангилем обозначает эту вольность фразой «смесь философии без строгости с этикой без требований и медициной без контроля» (Кангилем, 2012, с. 212). Однако, на его взгляд, она слишком вольна для той науки, которая требует научной институционализации.

Почему психология слишком вольна для науки? На этот вопрос Кангилем отвечает, обращаясь к пресловутой проблеме ее единства. Остов понятий и методов психология выстраивает через свой собственный предмет. Она постулирует себя как новую науку о психике и объединяет разнородные теории на основании изучения некой данной области фактов. Тем самым психология в принципе является целостным проектом теоретического сознания, но, по убеждению Кангилема, не единой наукой с методом и связной системой понятий. Этот своеобразный перевертыш: стремление к единству теории, но сохранение противоречивости методологии он называет скорее не научным фундаментом, а «соглашением о мирном сосуществовании» (Там же, с. 213).

\footnotetext{
${ }^{4}$ Выступление опубликовано в 1958 г. (Revue de Métaphysique et de Morale. 1958. № 1). Однако, учитывая тот факт, что Фуко работал над энциклопедической статьей для А. Гисмана в 1952-1953 гг. (Huisman, 1990), вопрос о влиянии или общем поле дискуссий здесь требует прояснения.
} 
Полемизируя с Лагашем и его попыткой установить единство теорий, но не методов, Кангилем обращается к критике психологии в тех полярностях, которые тем были выделены, и приходит к выводу о том, что психология, освободившись от пут философской спекуляции, утратила идею человека, которая ранее стояла за психологией философской, или антропологической, и человек стал разменной монетой разных психологических теорий. «Кангилем здесь... показывает намерение психологии: она придает своему объекту человеку как инструменту функциональность и постоянство, и человек становится фиксированным местом в сети обмена» (Milner, 1966, p. 73), - подчеркивает в предисловии к речи Ж.-А. Милнер.

Робер Паж в своем комментарии к выступлению Кангилема, разбирая его позицию, говорит о том, что тот так и не разъясняет связи между философией как способом исследования значения и антропологией и так и не увязывает психологию как либертарианский проект с философской спекуляцией, однако его позиция предполагает эту связь (Pages, 1966, p. 97). Несмотря на философско-научную и историко-научную направленность, критика Кангилема начинает восприниматься в этом психологистском ключе.

Если свести фигуры и идеи Политцера и Лагаша, Сартра, Фуко и Кангилема в единой перспективе, отвлекаясь от составления парных дихотомий (что обычно делают исследователи), не ограничиваясь выводами об определяющем влиянии Политцера, не дробя перспективу на школы и направления (марксизм, экзистенциальную философию, эпистемологию), то философскую критику психологии во Франции 1920-1950-х гг. можно трактовать как переосмысление психологии как философской антропологии, как попытку сохранить за психологией тот ее смысл, который в классической психологии Просвещения закрепил за ней К. Вольф (см.: Goubet, 2003).

Просвещенческая светская философия воспринимала психологию как психологию аффектов и пыталась избавиться от обязательного восхождения к философии, однако проделывала это не ради утверждения ее главенства, а ради отстаивания ее самостоятельности. «В эпоху Просвещения онтология уступает место метафизике мыслительной деятельности...» - пишет П. Шоню (Шоню, 2008, с. 329). Психология просветителей была жизненной мудростью, знанием характеров и души. Формирование на французской сцене психологизма и философского «антипсихологизма» связано с тем, что психология стала воспринимать себя не как самостоятельную или подчиненную, но как главенствующую дисциплину. Однако этих содержательных сдвигов самих по себе оказалось еще недостаточно. Сциентизация философии, да и исследования человека в общем, отвечавшая духу французского позитивизма, сошлась во времени с окончанием первой фазы институционализации психологии, и в этой точке мы видим акцентирование психологистских и антипсихологистских настроений.

В эти годы для Франции значимым оказывается формирование разношерстного предметного поля наук о человеке: психологии, философии, психиатрии, психоанализа 5 . Это даже не междисциплинарное пространство

\footnotetext{
${ }^{5}$ Об институциональной истории психологии в контексте этого процесса см.: Carroy, 2015.
} 
взаимодействия, поскольку никакой междисциплинарности здесь не формируется, не структурируется самой дисциплинарности. Это также и не пространство четких школ. Справедливым описанием дел в области философии и психологии оказывается то, которое дает по отношению к французской философии как таковой В. Декомб, который подчеркивает: «Современную французскую философию” нельзя отождествлять ни с эпохой в развитии философии, ни с какой-либо одной школой. Она совпадает с совокупным дискурсом, имеющим место во Франции и рассматриваемым сегодняшней публикой как философский» (Декомб, 2000, с. 8). Дискурс психологии и философии также является не полярным дискурсом наук или направлений, а скорее общим пространством интереса, направленного на человека во всех его проявлениях и сферах жизни, - критическим антропологическим дискурсом.

Может ли психология в том виде, в котором она функционирует как наука, стать основанием философского учения о человеке? Может ли стать эмпирическим фундаментом философии? Может ли выступить мостом, связывающим философию с естественными науками? На все эти вопросы французская философская критика дает отрицательные ответы. Принимая психологию в качестве одной из составляющих многоликого поля гуманитарных наук, философия закономерно ее антропологизирует, настаивает на корректировке ее постулатов и методов, стремится переработать ее по шаблону «философии», всегда подчеркивая, что та не может функционировать, ориентируясь исключительно на естественные науки. Она не допускает самостоятельности психологии и признает ее значение для науки только в философском модусе. И такая критика выглядит вполне в традиции «спора о психологизме» в его французской специфике и его своеобразии в контексте философии 1920-1950-х гг.

\section{Литература}

Бен-Дэвид, Дж., Коллинз, Р. (2006) Социальные факторы при возникновении новой науки: случай психологии. В кн. Журнал «Логос». 1991-2005. Избранное (т. 1, с. 26-53). М.: Территория будущего.

Блауберг, И. И. (2003). Анри Бергсон. М.: Прогресс-Традиция.

Власова, О. А. (2009). Ранний Фуко: до «структуры», «археологии» и «власти». В кн. М. Фуко, Психическая болезнь и личность (пер. О. А. Власовой, с. 5-62). СПб.: Гуманитарная академия. Власова, О. А. (2015). «Антропологический сон» Мишеля Фуко: ранние работы. В кн. М. Фуко, Ранние работы (пер. О. А. Власовой, с. 3-82). СПб.: Владимир Даль.

Декомб, В. (2000). Современная франиузская философия. М.: Весь мир.

Кангилем, Ж. (2012). Что такое психология? Эпистемология и философия науки, 1, 212-225.

Кротов, А. А. (2000). Философия Мен де Бирана. М.: Изд-во Московского университета.

Кротов, А. А. (2003). Трактовка сознания в «эклектическом спиритуализме» В. Кузена. В кн. Философия сознания: история и современность (с. 121-127). М.: Современные тетради.

Куренной, В. (2002). Философия и институты: случай феноменологии. Логос, 5/6(35), 135-161. Куренной, В. (2010). Психологизм и его критика Эдмундом Гуссерлем. Логос, 5(78), 166-182. 
Куш, М. (2002). Социология философского знания: конкретное исследование и защита. Логос, 5-6(35), 104-134.

Куш, М. (2004). Победителю достается все: Философия жизни и триумф феноменологии. Логос, $3(43), 167-200$.

Лакан, Ж. (2008). Изнанка психоанализа. Семинар, Книга XVII (1969-70). М.: Гнозис/Логос.

Мотрошилова, Н. В. (1968). Принципы и противоречия феноменологической философии. М.: Высшая школа.

Мотрошилова, Н. В. (2003). «Идеи I» Эдмунда Гуссерля как введение в феноменологию. М.: Феноменология-Герменевтика.

Политцер, Ж. (1980). Избранные философские и психологические труды. М.: Прогресс.

Сартр, Ж.-П. (2004). Бытие и ничто: Опыт феноменологической онтологии. М.: Республика.

Фуко, М. (2015). Ранние работы. СПб.: Владимир Даль.

Шоню, П. (2008). Цивилизащия Просвещения. Екатеринбург/М.: У-Фактория/АСТ.

Ссылки на зарубежные источники см. в разделе References после англоязычного блока.

Власова Ольга Александровна - профессор, кафедра истории философии, Институт философии, Санкт-Петербургский государственный университет, доктор философских наук.

Сфера научных интересов: история философии $\mathrm{XX}$ в., философия психиатрии, философская психология.

Контакты: o.a.vlasova@gmail.com

\title{
The Critique of Psychology in French Philosophy of the Mid-Twentieth Century in the Light of the "Psychologism Dispute"
}

\author{
O.A. Vlasova ${ }^{\mathrm{a}}$ \\ ${ }^{a}$ Saint Petersburg State University, 7/9 Universitetskaya emb., Saint Petersburg, 199034, Russian \\ Federation
}

\begin{abstract}
The paper discusses the philosophical critique of psychology in France 1940 50's in the light of the psychologism dispute and on the ideas of G. Politzer, J.-P. Sartre, D. Lagach, G. Canguilhem, M. Foucault. The productivity of the terminology of the «psychologism dispute» to the French situation and the national specifics of critique are shown. The author demonstrates that psychologists and philosophers confront each other not directly, but in the field of philosophical anthropology; here psychology pretends to occupy not the place of philosophy, but the place of the basic humanitarian discipline. In France philosophical critique of psychology develops later than in Germany; a longer process of separating psychology from philosophy is the cause of it. The paper shows a chronology of development of psychology as a two-stage process of its institutionalization as a science (1870-1940s) and a specialty (1940-2000s). A peak of
\end{abstract}


philosophical criticism is the 1940s-1950s: the decade when psychology receives the right to a licentiate. Psychologism in France of 1940-50's is connected with psychology's claim to become the basis of anthropology. Antipsychologism, developed within the framework of philosophical critique of psychology, was the attempt to defend the philosophical status of anthropology and to prove that anthropology can comprehend a person as integrity if keep its philosophical foundations. Philosophers accentuate two problematic points of psychology: 1) lack of integrity, multidirectional theories and explanatory schemes, 2) pre-scientific or mythological nature of its postulates. They regard philosophical criticism as propaedeutic to anthropology (materialistic or existential) and interpret psychology as the starting point of a new Kantian project and a new philosophy of science (as a science of man). The author marks in this movement the vector "Politzer - Sartre - Lagache - Canguilhem - Foucault" and analyzes in detail their criticism.

Keywords: French philosophy, psychology, anthropology, psychologism dispute, antipsychologism, J.-P. Sartre, G. Politzer, D. Lagach, G. Canguilhem, M. Foucault.

\section{References}

Althusser, L. (1996). La place de la psychanalyse dans les sciences humaines [The place of psychoanalysis in the humanities]. In Psychanalyse et sciences humaines deux conférences (1963-1964) [The psychoanalysis and humanities: Two conferences (1963-1964)] (pp. 17-72). Paris: Librairie générale. (in French)

Ben-David, J., \& Collins, R. (2006). Sotsial'nye faktory pri vozniknovenii novoi nauki: sluchai psikhologii [Social factors in the origins of a new science: The case of psychology]. In Zhurnal Logos. 1991-2005. Izbrannoe [Selected papers] (Vol. 1, pp. 26-53). Moscow: Territoriya budushchego Publ. (in Russian)

Bernet, R., Kern, I., \& Marbach, E. (1993). Introduction to Husserlian phenomenology. Evanston, IL: Northwestern University Press.

Bianco, G. (2015). La signification du concret. Philosophie et psychologie chez Georges Politzer [The significance of the concrete. Philosophy and psychology in Georges Politzer's works]. Paris: Hermann. (in French)

Blauberg, I. I. (2003). Henry Bergson. Moscow: Progress-Traditsiya. (in Russian)

Braunstein, J.-F. (2012). The French invention of "Psychologism" in 1828. Revue d'Histoire des Sciences, 2(65), 197-212. doi:10.3917/rhs.652.0197

Canguilhem, G. (1966). Le normal et la pathologique [The normal and the pathological]. Paris: PUF. (in French)

Canguilhem, G. (2012). Chto takoe psikhologiya? [What is the psychology?]. Epistemologiya $i$ Philosophiya Nauki [Epistemology and Philosophy of Science], 1, 212-225. (in Russian)

Carroy, J. (2015). La "psychologie" au Collège de France [Chairs in "Psychology" at the Collège de France]. Revue Philosophique de la France et de L'Étranger, 2(140), 225-228. doi:0.3917/rphi.152.0225 (in French)

Carroy, J., Ohayon, A., \& Plas, R. (2006). Histoire de la psychologie en France: XIX ${ }^{e}-X X^{e}$ ciècles [The history of French psychology: XIX-XX centuries]. Paris: La Découverte. (in French)

Chaunu, P. (2008). Tsivilizatsiya Prosveshcheniya [The civilization of Classical Europe]. Ekaterinburg/Moscow: U-Faktoriya/AST. (in Russian) (Transl. of: Chaunu, P. (1966). La civilisation de l'Europe classique [The civilization of Classical Europe]. Paris: Arthaud. (in French)) 
Descombes, V. (1989). Vers une crise d'identité en philosophie française: Merleau-Ponty, Hyppolite, Canguilhem [The crisis of identity in French philosophy: Merleau-Ponty, Hyppolite, Canguilhem]. In Les enjeux philosophiques des années 50 (pp. 147-167). Paris: Centre Georges Pompidou. (in French) Descombes, V. (2002). Sovremennaya frantsuzskaya filosofiya [The modern French philosophy]. Moscow: Ves' Mir. (in Russian)

Engel, P. (1966). Psychilogie et philosophie [Psychology and philosophy]. Paris: Gallimard. (in French)

Foucault, M. (2001). Philosophie et psychologie (entretien avec A. Badiou) [Philosophy and psychology: the interview with A. Badiou]. In M. Foucault, Dits et écrits II, 1954-1975 [Sayings and writings] (pp. 466-476). Paris: Gallimard. (in French)

Foucault, M. (2015). Rannie raboty [Early works]. Saint Petersburg: Vladimir Dal'. (in Russian)

Fruteau de Laclos, F. (2015). La métaphysique des forces et les forms du psychisme Deleuze, Sartre et les autres [The metaphysics of forces and the forms of the mental. Deleuze, Sartre, and the others]. Revue Philosophique de la France et de L'Étranger, 2(140), 149-168. doi:10.3917/rphi.152.0149 (in French)

Goubet, J.-F. (2003). Psychologie et métaphysique. Autour de Christian Wolff [Psychology and metaphysics: Christian Wolff]. Revue Philosophique de la France et de l'Étranger, 3(128), 275-277. doi:10.3917/rphi.033.0275 (in French)

Hopkins, B. C. (2006). Husserl's Psychologism, and Critique of Psychologism, Revisited. Husserl Studies, 2(22), 91-119. doi:10.1007/s10743-006-9008-5

Huisman, D. (1990). Note sur l'article de Michel Foucault [Replay to Michel Foucault's paper]. Revue Internationale de Philosophie, 173, 177-178. (in French)

Krotov, A. A. (2000). Filosofiya Men de Birana [Maine de Biran's philosophy]. Moscow: Moscow University Press. (in Russian)

Krotov, A. A. (2003). Traktovka soznaniya v “eklekticheskom spiritualizme” V. Kuzena [Consciousness in V. Cousin's eclectic spiritualism]. In Filosofija soznanija: istorija i sovremennost' [The philosophy of Consciousness: Past and Present] (pp. 121-127). Moscow: Sovremennye tetradi. (in Russian)

Kurennoy, V. (2002). Filosofiya i instituty: sluchai fenomenologii [Philosophy and the institutes: the case of phenomenology]. Logos, 5/6(35), 135-161. (in Russian)

Kurennoy, V. (2010). Psikhologizm i ego kritika Edmundom Gusserlem [Psychologism and its critics by Edmund Husserl]. Logos, 5(78), 166-182. (in Russian)

Kusch, M. (2002). Sotsiologiya filosofskogo znaniya: konkretnoe issledovanie i zashchita [The sociology of philosophical knowledge: A case study and a defense]. Logos, 5/6(35), 104-134. (in Russian)

Kusch, M. (2004). Pobeditelyu dostaetsya vse: Filosofiya zhizni i triumf fenomenologii [Winner takes it all: Lebensphilosophie and the triumph of phenomenology]. Logos, 3(43),167-200. (in Russian)

Kusch, M. (2005). Psychologism. A case study in the sociology of philosophical knowledge. London/New York: Routledge.

Lacan, J. (2008). Iznanka psikhoanaliza. Seminar, Kniga XVII (1969-70) [Seminars. Book XVII. The other side of psychoanalysis]. Moscow: Gnozis/Logos. (in Russian)

Lagache, D. (1949a). L'esprit de la psychologie contemporaine [The spirit of the modern psychology]. L'Année Psychologique, 1(50), 1-10. (in French)

Lagache, D. (1949b). Lunité de la psychologie [The unity of psychology]. Paris: PUF. (in French)

Milner, J.-C. (1966). Avertissement [Introduction]. Concept and Form: The Cahiers pour l'Analyse and Contemporary French Thought, 2, 73-74. (in French)

Mohanty, J. N. (1997). The concept of "Psychologism" in Frege and Husserl. Philosophy and Rhetoric, 3(30), 271-290. 
Motroshilova, N. V. (1968). Printsipy i protivorechiya fenomenologicheskoi filosofii [Principles and contradictions of the phenomenological philosophy]. Moscow: Vysshaya shkola. (in Russian)

Motroshilova, N. V. (2003). "Idei I" Edmunda Gusserlya kak vvedenie v fenomenologiyu [Edmund Husserl's "Ideen I" as the introduction to the phenomenology]. Moscow: FenomenologiyaGermenevtika. (in Russian)

Mouzet, J. (2015). Psychologie de Sartre [Sartre's psychology]. Revue Philosophique de la France et de L'Étranger, 2(140), 169-186. doi:10.3917/rphi.152.0169 (in French)

Pages, R. (1966). Quelques remarques sur "Qu'est-ce que la psychologie" [Some remarks on "What is the psychology"]. Concept and Form: The Cahiers pour l'Analyse and Contemporary French Thought, 2, 92-98. (in French)

Politzer, G. (1928). Critique des fondements de la psychologie [The critics of foundations of psychology]. Paris: PUF. (in French)

Politzer, G. (1980). Izbrannye filosofskie i psikhologicheskie trudy [Selected psychological and philosophical works]. Moscow: Progress. (in Russian)

Rath, M. (1994). Der Psychologismusstreit in der deutschen Philosophie [The psychologism dispute in German philolophy]. Freiburg: Alber. (in German)

Roudinesco, É. (1993). Situation d'un texte: “Qu'est-ce que la psychologie?” [Situation of the text: "What is the psychology?”]. In Georges Canguilhem: Philosophe, historien des sciences [Georges Canguilhem: philosopher, historian of the sciences] (pp. 135-144). Paris: Albin Michel. (in French)

Sartre, J.-P. (2004). Bytie i nichto: Opyt fenomenologicheskoi ontologii [Being and nothingness: An essay on phenomenological ontology]. Moscow: Respublika. (in Russian) (Transl. of: Sartre, J.-P. (1943). L'Etre et le Néant [Being and nothingness]. Paris: Éd. Gallimard. (in French))

Scudéri, Ch. (2012). Esquisse d'une généalogie de la psychologie française: "L'unité de la psychologie" par Daniel Lagache (1949-1969) [The study of genealogy of French psychology: Daniel Lagache's "The unity of psychology"]. Lille: Atelier national de reproduction des thèses. (in French)

Sober, E. (1978). Psychologism. Journal for the Theory of Social Behaviour, 2(8), 165-192. doi:10.1111/j.1468-5914.1978.tb00398.x

Tomè, A. (2012). Sartre et la critique des fondements de la psychologie: Quelques pistes sur les rapports de Sartre et de Politzer [Sartre and the critics of the foundations of psychology: sceneries of Sartre and Politzer]. Bulletin d'Analyse Phénomenologique, 1(viii), 223-244. (in French)

Varga, P. A. (2010). Psychologism as positive heritage of Husserl's phenomenological philosophy. Studia Phänomenologica, 10, 135-161. doi:10.7761/SP.10.135

Vlasova, O. A. (2009). Rannii Foucault: do "struktury", "arkheologii” i "vlasti” [Early Foucault: before "structure”, "archeology” and "authority”]. In M. Foucault, Psikhicheskaya bolezn' i lichnost' [Mental illness and personality] (transl. O. A. Vlasova, pp. 5-62). Saint Petersburg: Gumanitarnaya Academiya. (in Russian)

Vlasova, O. A. (2015). "Antropologicheskii son” Mishelya Fuko: rannie raboty [Michel Foucault's "anthropological dream": early works]. In M. Foucault, Rannie raboty [Early works] (transl. O. A. Vlasova, pp. 3-82). Saint Petersburg: Vladimir Dal'. (in Russian)

Olga A. Vlasova - professor, Department of History of Philosophy, Institute of Philosophy, Saint-Petersburg State University, D.Sc.

Research area: 20th century philosophy, philosophy of psychiatry, philosophical psychology.

E-mail: o.a.vlasova@gmail.com 